\title{
SYNERGISTIC EFFECT OF PROPOLIS AND ANTIBIOTICS ON THE SALMONELLA TYPHI
}

\author{
Ricardo de Oliveira Orsi ${ }^{1 *}$; José Maurício Sforcin²; Silvia Regina Cunha Funari'; \\ Ary Fernandes Junior ${ }^{2}$; Vassya Bankova ${ }^{3}$
}

${ }^{1}$ Departamento de Produção e Exploração Animal, Faculdade de Medicina Veterinária e Zootecnia, Universidade Estadual Paulista, Botucatu, SP, Brasil; ${ }^{2}$ Departamento de Microbiologia e Imunologia, Instituto de Biociências, Universidade Estadual Paulista, Botucatu, SP, Brasil; ${ }^{3}$ Institute of Organic Chemistry with Centre of Phytochemistry, Bulgarian Academy of Sciences,

Sofia, Bulgaria

Submitted: March 18, 2005; Approved: March 15, 2006

\begin{abstract}
The goal of this work was to investigate a possible synergistic effect between ethanolic extracts of propolis from Brazil and Bulgaria and some antibiotics (Amoxicillin, Ampicillin and Cefalexin) against Salmonella Typhi. Brazilian and Bulgarian propolis showed an antibacterial action, but the sample from Bulgaria was shown to be more efficient. Both samples showed a similar synergistic effect with these antibiotics. One may conclude that the propolis samples show an important antibacterial action, as well as a synergistic effect with antibiotics against Salmonella Typhi.
\end{abstract}

Key words: propolis, antimicrobial activity, antibiotics, synergistic effect

\section{INTRODUCTION}

Salmonella serovars are responsible for human diseases that range from mild gastroenteritis to host-disseminated enteric fever (12).

Bacterial drug resistance is an important world problem $(1,23)$. Poppe et al. (14) verified that Salmonella serovars, isolated from food or infected animals, were resistant to several antibiotics. Lewin (9) and Stoner et al. (19) also reported an increased resistance of Salmonella serovars to several antimicrobial drugs.

Propolis is a resinous material produced by bees from plant buds and exudates, showing biological activities such as antibacterial (17). The chemical composition of propolis is very complex and is dependent upon the source plant. The main vegetal source of propolis in Botucatu, São Paulo State, Brazil, is Baccharis dracunculifolia DC., followed by Eucalyptus citriodora Hook and Araucaria angustifolia (Bert.) O. Kuntze (3). The brazilian propolis sample, collected in the Beekeeping Section of the University, was analysed by GC, GC-MS and TLC, revealing that its main components are phenolic compounds (flavonoids, aromatic acids, benzopyranes), di- and triterpenes, essential oils, among others. Seasonal variations in propolis composition are not significant and are predominantly quantitative $(2,4,6)$.

In order to reduce the clinical doses of most antibiotic compounds because of their marked side effects, we investigated a possible synergistic effect of propolis with some antibiotics that act on the bacteria wall, reducing the minimal inhibitory concentration (MIC) of 3 widely-used antibiotics: Amoxicillin, Ampicillin and Cefalexin.

\section{MATERIALS AND METHODS}

\section{Propolis samples}

Brazilian propolis was collected in the BeeKeeping Section of the School of Veterinary Medicine and Animal Husbandry of Botucatu, UNESP. Bulgarian propolis was given by Dr. Bankova, from the Bulgarian Academy of Sciences, Sofia.

Propolis samples were ground and extracted ( $30 \mathrm{~g}$ of propolis, completing the volume to $100 \mathrm{~mL}$ with $70 \%$ ethanol). The final concentrations were calculated, obtaining the dry weight of the

*Corresponding Author. Mailing address: Departamento de Produção e Exploração Animal, Faculdade de Medicina Veterinária e Zootecnia, UNESP, Distrito de Rubião Junior, s/n. 18618-000, Botucatu, SP, Brasil. Telefax: (+5514) 3811-7189, E-mail: orsi@ fca.unesp.br 
solutions (Brazil: $133 \mathrm{mg} / \mathrm{mL}$; Bulgaria: $170 \mathrm{mg} / \mathrm{mL}$ ). Specific dilutions of these solutions were prepared in appropriate media for each assay.

\section{Salmonella serovars}

A standard serovar of Salmonella Typhi (00238) was obtained from Fundação Oswaldo Cruz, Rio de Janeiro, Brazil, and maintained in tripticase soya agar (TSA/Oxoid) at room temperature.

\section{Susceptibility test: Propolis}

Determination of the minimal inhibitory concentrations (MIC) by the agar dilution method was performed, following the National Committee of Clinical Laboratory Standards Guidelines (11).

Serial concentrations of propolis from Brazil and Bulgaria were achieved ( $\% \mathrm{v} / \mathrm{v})$ in plates containing Mueller Hinton Agar, ranging from $1.0 \%$ to $14.0 \%$. Each antimicrobial test also included plates containing the culture medium plus ethanol, in order to obtain a control of the solvent antimicrobial effect.

Bacterial strain was grown in Brain Heart Infusion Agar (BHI) (Oxoid) at $37^{\circ} \mathrm{C} / 24 \mathrm{~h}$. After incubation, the bacteria was suspended in $5 \mathrm{~mL}$ of sterile saline and diluted to yield a final inoculum of approximately $1.0 \times 10^{6} \mathrm{CFU} / \mathrm{mL}$.

After the inoculation procedures, using a multiloop replicator, plates were incubated at $37^{\circ} \mathrm{C} / 24 \mathrm{~h}$ and $\mathrm{MIC}$ endpoints were read as the lowest concentration of propolis that resulted in no visible growth or haze on the surface of the culture medium. Populational analyses of data were carried out by calculating the MIC for $90 \%$ of the microorganism (17).

\section{Susceptibility test: antibiotic substances}

Antibiotic substances acting on the bacterial wall were used: Amoxicillin, Ampicillin and Cefalexin (SIGMA). They were water soluble, dissolved immediately prior to their use and filtered through a $0.22 \mu \mathrm{m}$ filter into vacuumed sterile pre-sealed vials, to obtain sterile solutions.

The MIC of these antibiotics was determined by serial dilutions in BHI, raging from $0.008 \mu \mathrm{g} / \mathrm{mL}$ to $1024.0 \mu \mathrm{g} / \mathrm{mL}$.

Aliquots $(20 \mu \mathrm{L})$ of bacterial suspensions $\left(1.0 \times 10^{6} \mathrm{CFU} /\right.$ $\mathrm{mL}$ ) of Salmonella Typhi were added to tubes containing BHI $(2.5 \mathrm{~mL})$ plus the antibiotics. Test tubes were incubated for $24 \mathrm{~h}$ at $37^{\circ} \mathrm{C}$ and $\mathrm{MIC}$ endpoints were read as the lowest concentration of antibiotics that resulted in no haze. All assays were carried out in triplicates.

\section{Survival curve and synergism}

The survival curve of Salmonella Typhi was performed in order to observe the incubation period responsible for propolis antibacterial activity. Thus, $1.0 \times 10^{6} \mathrm{CFU} / \mathrm{mL}$ were inoculated in BHI plus propolis in the corresponding MIC 90\%, obtained previously to each strain.
After 1.5, 3, 6, 9 and $24 \mathrm{~h}$ of incubation $\left(37^{\circ} \mathrm{C}\right)$, aliquots of each culture were recovered and plated on Mueller Hinton Agar by the Pour Plate method. Plate counts (CFU/mL) were carried out after $24 \mathrm{~h}$ incubation and the survival percentage was calculated (17)

A synergistic effect between propolis and antibiotics was observed, following the behavior of Salmonella Typhi incubated with $1 / 2$ and $1 / 4$ of Brazilian and Bulgarian propolis (MIC $90 \%$ ) plus $1 / 2$ or $1 / 4$ of each antibiotic, respectively.

\section{Statistical analysis}

Analysis of variance (ANOVA) was used to examine the treatment effects in the survival curve, according to the incubation period in medium plus Brazilian or Bulgarian propolis or antibiotics. The probability of 0.001 was chosen as the significant level (24).

\section{RESULTS AND DISCUSSION}

We could verify that Salmonella Typhi is susceptible to propolis from Brazil $(\mathrm{MIC}=9.9 \% \mathrm{v} / \mathrm{v})$ and Bulgaria $(\mathrm{MIC}=$ $10.0 \% \mathrm{v} / \mathrm{v}$ ) (Table 1). With regards to ethanol $70 \%$ effects, used as a solvent for propolis in this assay, its inhibitory action was seen only in the concentration of $12.6 \% \mathrm{v} / \mathrm{v}$.

Several authors have studied the antimicrobial activity of propolis $(7,15)$. It was reported that propolis shows a marked action against Gram-positive bacteria and a limited activity against Gram-negative ones (17). We could also observe that the MIC for Salmonella Typhi was far above the MIC from Grampositive bacteria (0.5\% v/v for Staphylococcus aureus) (17).

Brazilian and Bulgarian samples had similar MIC (9.90 and $10.0 \%$, respectively). However, their action on the Salmonella survive was significantly different: bacteriostatic activity to Brazilian and bactericidal to Bulgarian propolis (Table 1). Since these samples were produced in distinct geographic regions, differences in their chemical composition are expected, what could be also related to different biological activities.

Salmonella Typhi susceptibility to antibiotics is variable, depending on the serovar and the resistance to antibiotic

Table 1. Minimal inhibitory concentration (MIC) of Brazilian and Bulgarian propolis and antibiotics (amoxicillin, ampicillin and cefalexin) for Salmonella Typhi.

\begin{tabular}{ccc}
\hline Treatment & MIC $90 \%$ & Activity \\
\hline Brazilian propolis & $9.90 \% \mathrm{v} / \mathrm{v}(247.5 \mathrm{mg} / \mathrm{mL})$ & bacteriostatic \\
Bulgarian propolis & $10.00 \% \mathrm{v} / \mathrm{v}(260 \mathrm{mg} / \mathrm{mL})$ & bactericidal \\
Amoxicillin & $8 \mu \mathrm{g} / \mathrm{mL}$ & bactericidal \\
Ampicillin & $8 \mu \mathrm{g} / \mathrm{mL}$ & bactericidal \\
Cefalexin & $64 \mu \mathrm{g} / \mathrm{mL}$ & bactericidal \\
\hline
\end{tabular}


substances $(5,13)$. Threlfall (21) related that Salmonella Typhi serovars, isolated in India and southwest of Asia, were resistant to several antimicrobial drugs, showing a high level of epidemic in these regions. The data showed that antimicrobial drugs inhibited Salmonella Typhi growth, showing a bactericidal effect (Table 1).

In order to verify the synergistic effect, we used the $1 / 2$ and $1 / 4$ of the minimal inhibitory concentration of propolis samples and the antibiotics, obtained previously (Table 1 ).

The combination of $1 / 2$ and $1 / 4$ of the MIC of Brazilian propolis and Amoxicillin had a remarkable inhibitory effect on Salmonella Typhi, after 3 and $6 \mathrm{~h}$ of incubation, respectively. A similar result was observed with Bulgarian propolis (Fig. 1).

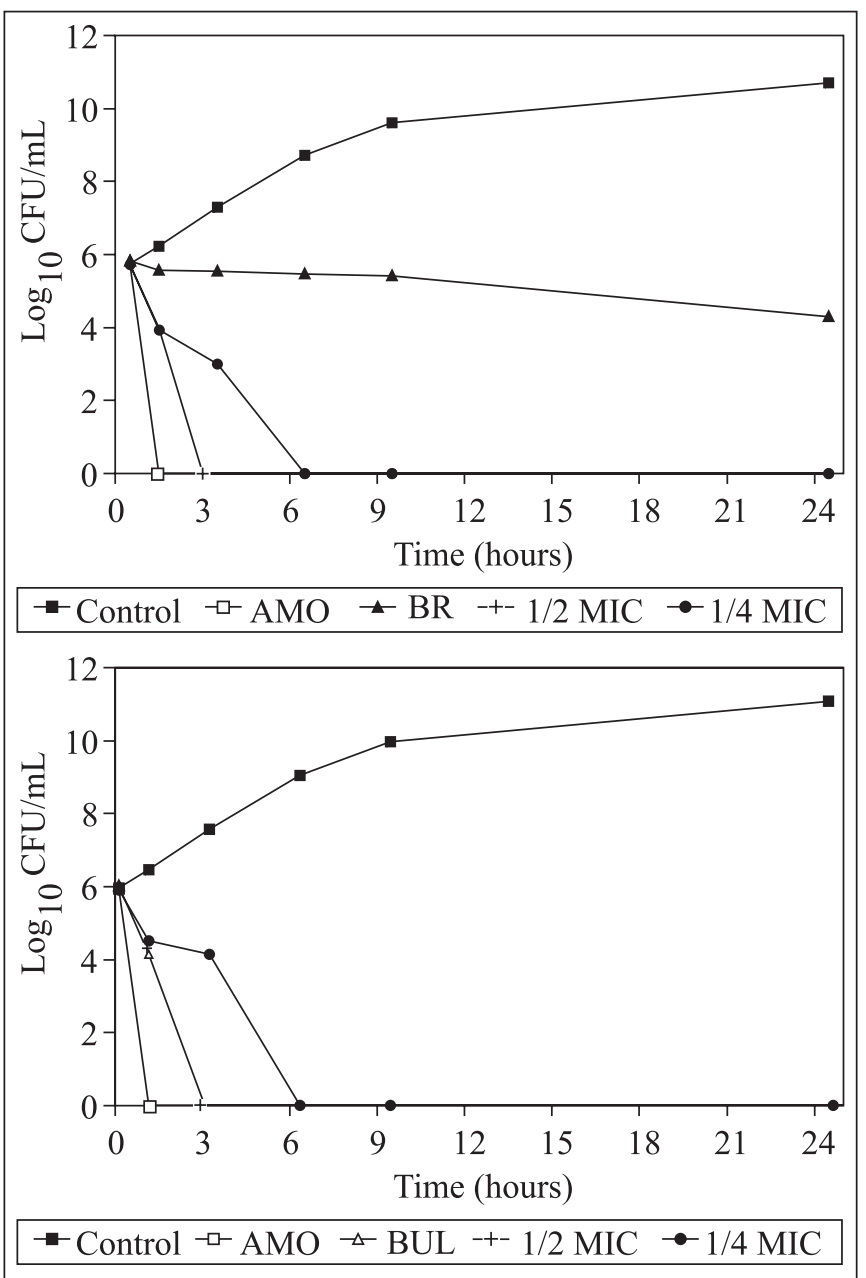

Figure 1. Profile in time (h) of the population analysis of Salmonella Typhi according to susceptibility to Brazilian propolis - BR (9.9\% v/v), Bulgarian propolis - BUL (10.0\%) and Amoxilina - AMO $(8.0 \mu \mathrm{g} / \mathrm{mL})$, with $1 / 2$ and $1 / 4$ of the minimal inhibitory concentration (MIC).
With regards to Ampicillin, one may observe that $1 / 2$ and $1 / 4$ of Brazilian propolis and antibiotic had an efficient reduction in the CFU of Salmonella Typhi (Fig. 2), showing a bactericidal effect after 3 and $6 \mathrm{~h}$, respectively. Bulgarian propolis also reduced the $\mathrm{CFU}$, showing a bactericidal effect for both relations ( $1 / 2$ and $1 / 4$ ) after $6 \mathrm{~h}$ of incubation (Fig. 2).

The combination of Cefalexin and Brazilian propolis reduced significantly the CFU of Salmonella Typhi, having a bactericidal effect after $9(1 / 2)$ and $24 \mathrm{~h}(1 / 4)$. With respect to Bulgarian propolis, there was also a synergistic effect with Cefalexin and a bactericidal effect after $3 \mathrm{~h}$ of incubation ( $1 / 2$ and $1 / 4)$ (Fig. 3).

Beta-lactamic antibiotics (Amoxicillin, Ampicillin and Cefalexin) act on a group of proteins called "Penicillin-binding-
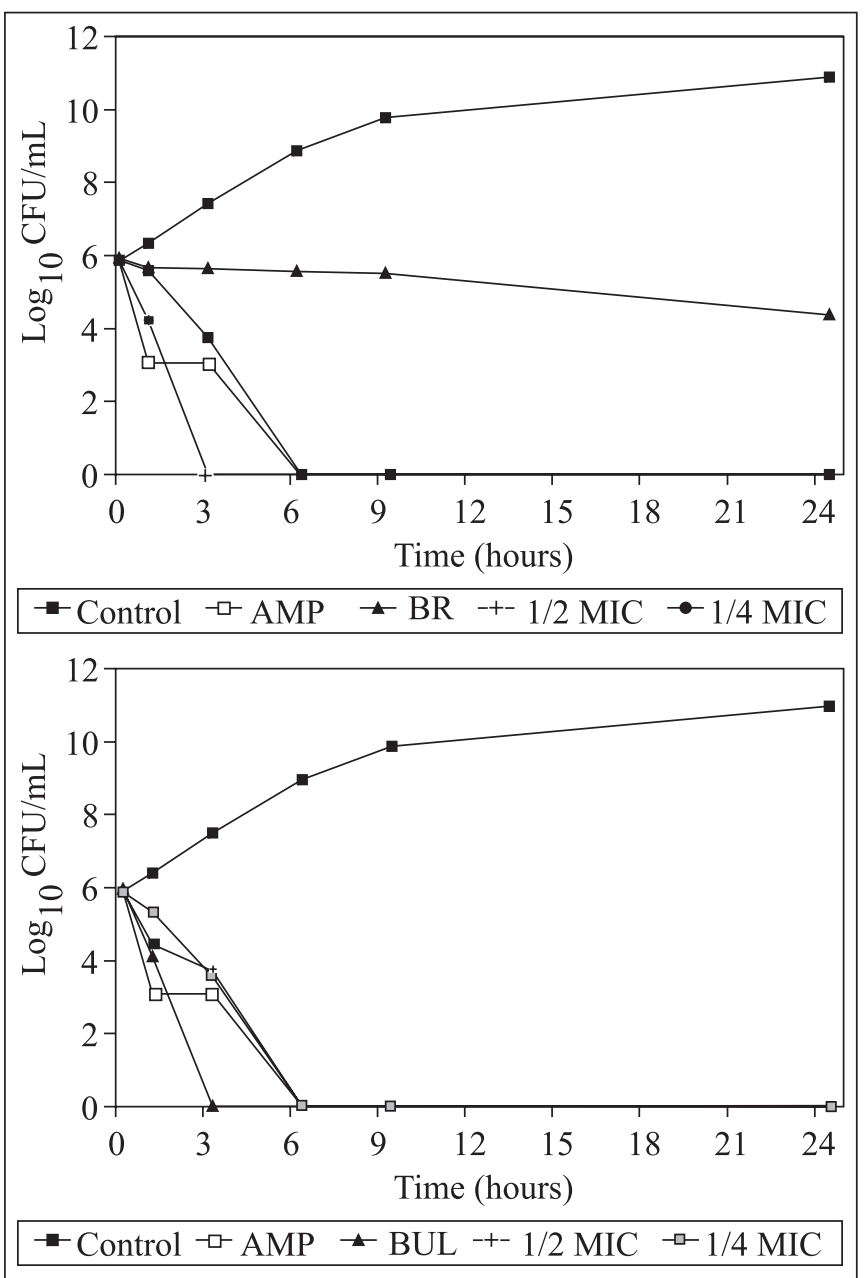

Figure 2. Profile in time (h) of the population analysis of Salmonella Typhi according to susceptibility to Brazilian propolis - BR (9.9\% v/v), Bulgarian propolis - BUL (10.0\%) and Ampicillin - AMP $(8.0 \mu \mathrm{g} / \mathrm{mL})$, with $1 / 2$ and $1 / 4$ of the minimal inhibitory concentration (MIC). 

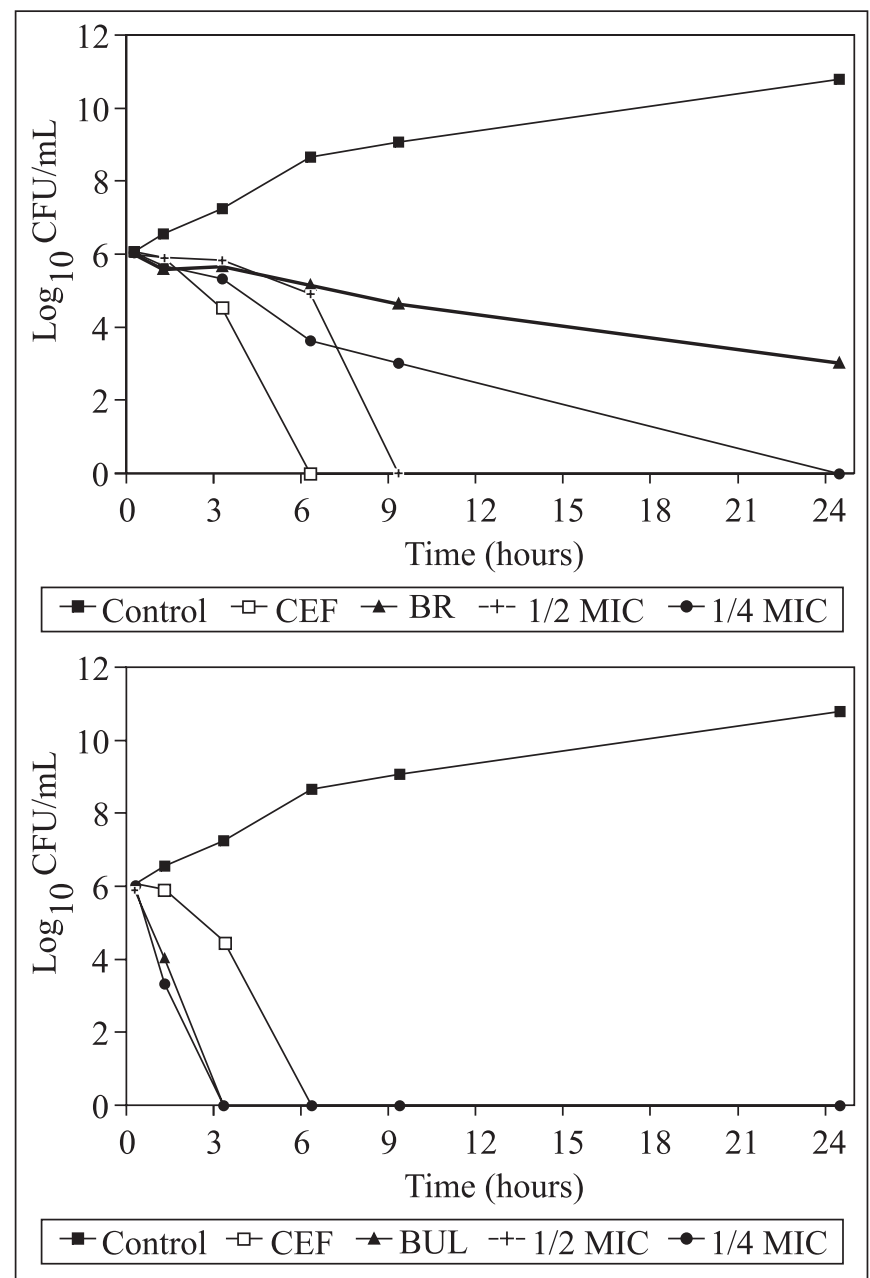

Figure 3. Profile in time (h) of the population analysis of Salmonella Typhi according to susceptibility to Brazilian propolis - BR $(9.9 \% \mathrm{v} / \mathrm{v})$, Bulgarian propolis - BUL $(10.0 \%)$ and Cefalexina - CEF $(64.0 \mu \mathrm{g} / \mathrm{mL})$, with $1 / 2$ and $1 / 4$ of the minimal inhibitory concentration (MIC).

proteins" (PBP), found in the periplasmatic space of Gramnegative bacteria. These PBP are involved in the peptideoglican synthesis - an important structure of bacteria wall (18).

Although little is known about the mechanisms of propolis antibacterial action, Takaisi-Kikuni and Schilder (20) verified that ethanolic extract of propolis acted on S. agalactie growth, inhibiting the protein synthesis. Mirzoeva et al. (10) reported that propolis and some of its cinnamic and flavonoid components were found to uncouple the energy transducing cytoplasmic membrane and to inhibit bacterial motility. Koo et al. (7) suggested that propolis could act on the enzymatic activity of $S$. mutans and $S$. sangui.

Krol et al. (8) related that propolis had a marked synergistic effect on the antibacterial activity of streptomycin and cloxacillin towards Staphylococcus aureus. Scheller et al. (16) observed a synergistic effect between an ethanolic extract of propolis and antibiotics used against mycobacteria.

In our work, propolis seemed to aid beta-lactamic antibiotics in PBP inhibition, what could explain the synergistic effects. Besides, propolis could also diminish the resistance of the bacteria wall to antibiotics, as suggested by Mirzoeva et al. (10), promoting beta-lactamics action on PBP.

\section{CONCLUSION}

We conclude that Brazilian and Bulgarian propolis had an antibacterial action on Salmonella Typhi, although the Bulgarian propolis shows to be more efficient that the Brazilian sample. Both samples show a similar synergistic effect with some antibiotics acting on the cell wall. This result is important to reduce the antibiotic clinical doses and their marked side effects.

\section{RESUMO}

\section{Efeito sinérgico da própolis e antibióticos sobre Salmonella Typhi}

O objetivo do presente trabalho foi investigar um possível efeito sinérgico entre extrato alcoólico de própolis do Brasil e Bulgária com alguns antibióticos (Amoxilina, Ampicilina e Cefalexina) utilizados contra Salmonella Typhi. Própolis do Brasil e Bulgária mostraram uma atividade antibacteriana, embora a amostra da Bulgária tenha sido mais eficiente. Ambas as amostras apresentaram um efeito sinérgico com os antibióticos estudados. Pode-se concluir que as amostras de própolis possuem atividade antibacteriana, bem como apresentam efeito sinérgico com antibióticos utilizados contra Salmonella Typhi.

Palavras-chave: própolis, atividade antibacteriana, antibióticos, efeito sinérgico

\section{REFERENCES}

1. Asna, S.M.Z.H.; Haq, J.A. Decrease of antibiotic resistance in Salmonella Typhi isolated from patients attending hospitals of Dhaka City over a 3 years period. Int. J. Antim. Agents, 16, 249-51, 2000.

2. Bankova, V.; Boudourova-Krasteva, G.; Popov, S.; Sforcin, J.M.; Funari, S.R.C. Seasonal variations of the chemical composition of Brazilian propolis. Apidologie, 29, 361-7, 1998a.

3. Bankova, V.; Boudourova-Krasteva, G.; Sforcin, J.M.; Frete, X.; Kujumgiev, A.; Maimoni-Rodella, R.; Popov, S. Phytochemical evidence for the plant origin of Brazilian propolis from São Paulo State. Z. Naturforsch., 54c, 401-5, 1999.

4. Bankova, V.; Boudourova-Krasteva, G.; Sforcin, J.M.; Frete, X.; Kujumgiev, A.; Rodella-Maimoni, R.; Popov, S. Phytochemical evidence for the plant origin of brazilian propolis from São Paulo State. Z. Naturforsch., 54c, 401-5, 1998 b.

5. Boonmar, S.; Bangtrakulnonth, A.; Pornruangwong, S.; Samosornsuk, S.B.; Kaneko, K; Ogawa, M. Significant increase in the antibiotic 
resistance of Salmonella isolates from human beings and chicken meat in Thailand. Vet. Microbiol., 62, 73-80, 1998.

6. Boudourova-Krasteva, G.; Bankova, V.; Sforcin, J.M.; Nikolova, N.; Popov, S. Phenolics from Brazilian propolis. Z. Naturforsch., 52c, 676-9, 1997.

7. Koo, H.; Rosalen, P.L.; Cury, J.A.; Park, Y.K.; Bowen, W.H. Effects of compounds found in propolis on Streptococcus mutans growth and on glucosyltransferase activity. Antimicrob. Agents Chemoth., 46, 1302-9, 2002.

8. Krol, W.; Scheller, S.; Shani, J.; Pietsz, G.; Zcuba, Z. Synergistic effect of ethanolic extract of propolis and antibiotics on the growth of Staphylococcus aureus. Drug Res., 43, 607-9, 1993.

9. Lewin, C.E. Treatment of multiresistant Salmonella infection. The Lancet, 337, 47, 1991

10. Mirzoeva, O.K.; Grishanin, P.C.; Calder, P.C. Antimicrobial action of propolis and some its components: the effects on growth, membrane potential and motility of bacteria. Microbiol. Res., 152, 239-46, 1997.

11. National Committee for Clinical Laboratory Standards. (NCCLS). Methods for dilution antimicrobial susceptibility tests for bacteria that grow aerobically. Approved Standard M7- A. NCCLS., Villanova, Pa. 1997.

12. Ohl, M.E.; Miller, S.I. Salmonella: a model for bacterial pathogenisis. Ann. Rev. Med., 52, 259-274, 2001.

13. Pang, T. Genetic dynamics of Salmonella Typhi - divestity in clonality. Trends Microbiol., 6, 339-42, 1998.

14. Poppe, C.; Aryoud, M.; Ollis, G.; Chirino-Trejo, M.; Smart, N.; Quessy, S.; Michel, P. Trends in antimicrobial resistance of Salmonella isolated from animals, foods of animal origin, and the environment of animal production in Canada, 1994-1997. Microbial Drug Resistance-Mechanisms Epidemiol. Dis., 7, 197-212, 2001.
15. Santos, F.A.; Bastos, E.M.A.; Uzeda, M.; Carvalho, M.A.R.; Farias, L.M.; Moreira, E.S.A.; Braga, F.C. Antibacterial activity of Brazilian propolis and fractions against oral anaerobic bacteria. $J$. Ethnopharmacol., 80, 1-7, 2002.

16. Scheller, S.; Dworniczak, S.; Klimmek, K.W.; Rajca, M.; Tomczyk, A.; Shani, J. Synergism between ethanolic extract of propolis (EEP) and anti-tuberculosis drugs on growth of Mycobacteria. $Z$. Naturforsch., 54, 549-53, 1999.

17. Sforcin, J.M.; Fernandes-Jr., A.; Lopes, C.A.M.; Bankova, V.; Funari, S.R.C. Seasonal effect on Brazilian propolis antibacterial activity. $J$. Ethonopharmacol., 73, 243-9, 2000.

18. Silva, J. Mechanisms of antibiotic resistance. Curr. Ther. Res., 57, 30-5, 2000.

19. Stoner, M.C.; Forsythe, R.; Mills, A.S.; Ivatury, R.R.; Broderick, T.J. Intestinal perforation secondary to Salmonella Typhi: case reported and review of the literature. Amer. Surg., 66, 219-22, 2000.

20. Takaisi-Kikuni, N.B.; Schilder, H. Electron microscopic and microcalorimetric investigations of the possible mechanism of the antibacterial action of a defined propolis provenance. Planta Med., 60, 222-227, 1994.

21. Threlfall, E.J. Antimicrobial drug resistance in Salmonella: problems and perspectives in food and water-borne infections. FEMS Microbiol. Rev., 26, 141-8, 2002.

22. Wolf, D.C.; Giannella, R.A. Antibiotic therapy for bacterial enterocolotis: a comprehensive review. Am. J. Gastroenterol., 88, 1667-83, 1993

23. World Health Organization (WHO). Surveillance Programme for Control of Foodborne Infections and Intoxications in Europe. Sixth report 1990-1992, 32-38. 1995.

24. Zar, J.H. Biostatistical analysis. New Jersey: Pretince Hall, 1996, $718 \mathrm{p}$. 